Article

\title{
Chemical Constituents from Flueggea virosa and the Structural Revision of Dehydrochebulic Acid Trimethyl Ester
}

\author{
Chih-Hua Chao ${ }^{1,2, *}$, Ying-Ju Lin ${ }^{3,4}$, Ju-Chien Cheng ${ }^{5}$, Hui-Chi Huang ${ }^{6}$, Yung-Ju Yeh ${ }^{5}$, \\ Tian-Shung $\mathrm{Wu}^{7,8}$, Syh-Yuan Hwang ${ }^{9}$ and Yang-Chang $\mathrm{Wu} 1,2,10,11, *$ \\ 1 School of Pharmacy, China Medical University, Taichung 40402, Taiwan \\ 2 Chinese Medicine Research and Development Center, China Medical University Hospital, \\ Taichung 40447, Taiwan \\ 3 School of Chinese Medicine, China Medical University, Taichung 40402, Taiwan; yjlin@mail.cmu.edu.tw \\ 4 Genetic Center, Department of Medical Research, China Medical University Hospital, \\ Taichung 40447, Taiwan \\ 5 Department of Medical Laboratory Science and Biotechnology, China Medical University, Taichung 40402, \\ Taiwan; jccheng@mail.cmu.edu.tw (J.-C.C.); star740101@gmail.com (Y.-J.Y.) \\ 6 Department of Chinese Pharmaceutical Sciences and Chinese Medicine Resources, China Medical University, \\ Taichung 40402, Taiwan; hchuang@mail.cmu.edu.tw \\ 7 Department of Pharmacy, National Cheng Kung University, Tainan 70101, Taiwan; tswu@mail.ncku.edu.tw \\ 8 Department of Pharmacy and Graduate Institute of Pharmaceutical Technology, Tajen University, \\ Pingtung 90741, Taiwan \\ 9 Endemic Species Research Institute, Council of Agriculture, Nantou 55244, Taiwan; \\ son757780@yahoo.com.tw \\ 10 Center for Molecular Medicine, China Medical University Hospital, Taichung 40447, Taiwan \\ 11 Graduate Institute of Natural Products, Kaohsiung Medical University, Kaohsiung 80708, Taiwan \\ * Correspondence: chaochihhua@hotmail.com (C.-H.C.); yachwu@mail.cmu.edu.tw (Y.-C.W.); \\ Tel.: +886-4-2205-3366 (ext. 5157) (C.-H.C.)
}

Academic Editor: Derek J. McPhee

Received: 9 August 2016; Accepted: 12 September 2016; Published: 16 September 2016

\begin{abstract}
In an attempt to study the chemical constituents from the twigs and leaves of Flueggea virosa, a new terpenoid, $9(10 \rightarrow 20)$-abeo-ent-podocarpane, $3 \beta, 10 \alpha$-dihydroxy-12-methoxy-13methyl-9(10 $\rightarrow$ 20)-abeo-ent-podocarpa-6,8,11,13-tetraene (1), as well as five known compounds were characterized. Their structures were elucidated on the basis of spectroscopic analysis. In addition, the structure of dehydrochebulic acid trimethyl ester was revised as (2S,3R)-4E-dehydrochebulic acid trimethyl ester based on a single-crystal $X$-ray diffraction study. The in vitro anti-hepatitis $C$ virus (anti-HCV) activity and cytotoxicity against Huh7.5 cells for the isolated compounds were evaluated.
\end{abstract}

Keywords: Flueggea virosa; dehydrochebulic acid trimethyl ester; ent-podocarpane; anti-HCV; HCVcc

\section{Introduction}

Flueggea virosa (Roxb. ex Wild) Baill, belonging to the Euphorbiaceae family, is a common medicinal plant in Africa and China [1,2]. In previous reports, Securinega alkaloids have been widely regarded as a representative group of the genus Flueggea [3], formerly classified as Securinega genus. However, our prior studies have demonstrated that the roots of F. virosa contained a series of non-alkaloids, including ent-podocarpanes [4,5], 9(10 $\rightarrow 20)$-abeo-ent-podocarpanes [6], 3,4-seco-ent-podocarpanes [7], and 3,4-seco-30-nor-friedelanes [6], some of which were endowed with anti-HCV activities and weak toxicities. Among them, 4-hydroxy-12-methoxy-13-methyl-3,4-secoent-podocarpa-6,8,11,13-tetraen-3-oic acid was found to be a brand new type anti-HCV 
agent [7]. The non-alkaloids in the other parts of this plant still received less attention. Thus, the isolation of active constituents from the twigs and leaves of F. virosa was carried out, which resulted in the isolation of a new $9(10 \rightarrow 20)$-abeo-ent-podocarpane, namely $3 \beta, 10 \alpha$-dihydroxy-12-methoxy-13-methyl-9(10 $\rightarrow 20)$-abeo-ent-podocarpa-6,8,11,13-tetraene (1), alone with five known compounds. In addition, the structural revision of dehydrochebulic acid trimethyl ester (Chart 1, original 2) was also reported in this study.

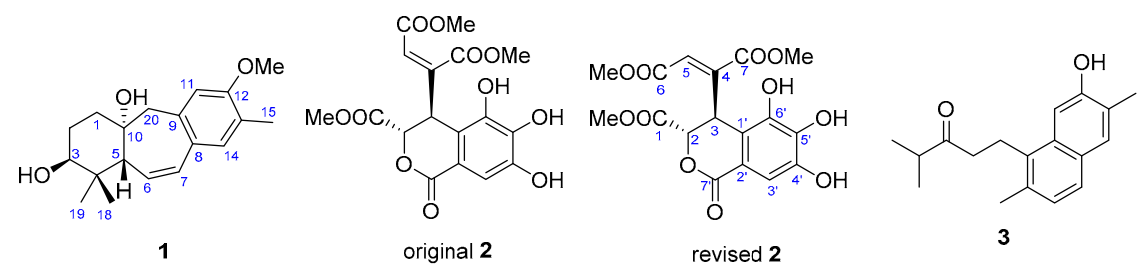

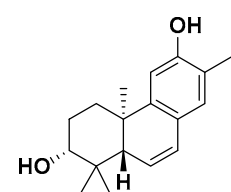

4

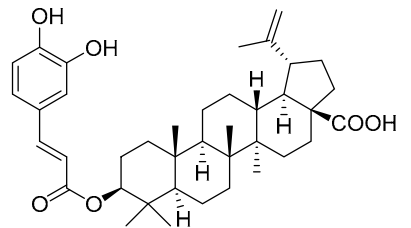

5<smiles>O=C1c2c(O)cc(O)cc2O[C@H](c2cc(O)c(O)c(O)c2)[C@H]1O</smiles>

6

Chart 1. Structures of compounds 1-6.

\section{Results and Discussion}

The $\mathrm{MeOH}$ extract from the twigs and leaves of F. virosa was concentrated and the alkaloids were removed by partition with acidic water. The resulting nonalkaloid layer was separated repeatedly by column chromatography to afford a new $9(10 \rightarrow 20)$-abeo-ent-podocarpane (1) and five known compounds, which were identified as $4 E$-dehydrochebulic acid trimethyl ester (2) [8,9], 12-hydroxy-20(10 $\rightarrow$ 5)-abeo-4,5-seco-podocarpa-5(10),6,8,11,13-pentaen-3-one (3) [10], 3ß,12-dihydroxy-13-methylpodocarpa-6,8,11,13-tetraene (4) [10], betulinic acid 3 $\beta$-calfeate (5) [11], and (+) ampelosin E (6) [12].

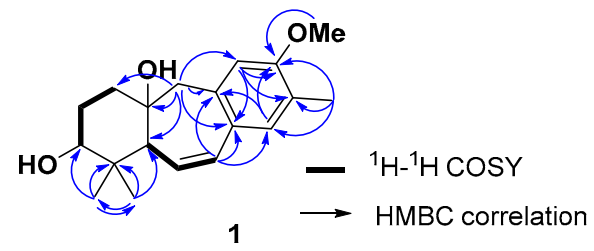

Figure 1. Selected ${ }^{1} \mathrm{H}-{ }^{1} \mathrm{H} \operatorname{COSY}(-)$ and $\operatorname{HMBC}(\rightarrow)$ correlations of $\mathbf{1}$.

Compound 1 was obtained as a colorless oil and a molecular formula of $\mathrm{C}_{19} \mathrm{H}_{26} \mathrm{O}_{3}$ was deduced for this compound based on the molecular ion peak $[\mathrm{M}-\mathrm{H}]^{-}$at $m / z 301.1805$ in the (-)-HR-APCI-MS (calcd for $\mathrm{C}_{19} \mathrm{H}_{25} \mathrm{O}_{3}, 301.1809$ ). Inspection of the overall ${ }^{1} \mathrm{H}$ - and ${ }^{13} \mathrm{C}-\mathrm{NMR}$ data revealed that it is a member of $9(10 \rightarrow 20)$-abeo-ent-podocarpanes [6], with slight chemical shift differences for resonances of substituent patterns. The 12-methoxy group was readily assigned from its proton chemical shift at $\delta_{\mathrm{H}} 3.82(\mathrm{~s})$, while the 6,7-double bond was deduced according to the proton chemical shifts at $\delta_{\mathrm{H}} 6.58(1 \mathrm{H}, \mathrm{dd}, J=12.1,2.6 \mathrm{~Hz})$ and $5.78(1 \mathrm{H}, \mathrm{dd}, J=12.1,4.4 \mathrm{~Hz})$ (Table 1) [6]. The above assignment was confirmed by the interpretation of ${ }^{1} \mathrm{H}-{ }^{1} \mathrm{H}$ COSY and HMBC correlations (Figure 1). The $3 \beta-\mathrm{OH}$ was determined based on the chemical shift and coupling patterns of $\mathrm{H}-3\left[\delta_{\mathrm{H}} 3.51\right.$ $(1 \mathrm{H}, \mathrm{t}, J=2.8 \mathrm{~Hz})]$. The relative configuration of 1 was further confirmed by the analysis of NOE correlations (Figure 2). The NOE correlations of $\mathrm{H}-5 / \mathrm{H}-20 \mathrm{a}, \mathrm{H}-5 / \mathrm{H}-1 \mathrm{a}$, and $\mathrm{H}-5 / \mathrm{H}_{3}-18$ confirmed that 1 
possessed the same relative configurations $(10 \alpha-\mathrm{OH}, 5 \beta-\mathrm{H})$ as those of $9(10 \rightarrow 20)$-abeo-ent-podocarpanes isolated previously from the roots of F. virosa [6] Accordingly, the structure of $\mathbf{1}$ was determined as $3 \beta, 10 \alpha$-dihydroxy-12-methoxy-13-methyl-9(10 $\rightarrow 20)$-abeo-ent-podocarpa-6,8,11,13-tetraene.

Table $1 .{ }^{1} \mathrm{H}$ - and ${ }^{13} \mathrm{C}-\mathrm{NMR}$ Spectroscopic Data (400 and $100 \mathrm{MHz}$, resp.; $\mathrm{CDCl}_{3}$ ) of $\mathbf{1}$.

\begin{tabular}{|c|c|c|c|}
\hline & \multicolumn{3}{|c|}{1} \\
\hline & $\delta_{H}(J$ in $\mathrm{Hz})$ & $\delta_{C}$ (Mult.) & НМВС \\
\hline 1 & $\begin{array}{c}2.05 \mathrm{td}(14.1,4.4) \\
1.61 \mathrm{~m}\end{array}$ & $33.0\left(\mathrm{CH}_{2}\right)$ & $2,3,20$ \\
\hline 2 & $\begin{array}{l}2.27 \mathrm{~m} \\
1.62 \mathrm{~m}\end{array}$ & $25.5\left(\mathrm{CH}_{2}\right)$ & 1 \\
\hline 3 & $3.51 \mathrm{t}(2.8)$ & $75.6(\mathrm{CH})$ & 1,5 \\
\hline 4 & & $38.2(\mathrm{C})$ & \\
\hline 5 & $2.45 \mathrm{dd}(4.4,2.6)$ & $49.6(\mathrm{CH})$ & $4,6,7,10,18,19$ \\
\hline 6 & $5.78 \mathrm{dd}(12.1,4.4)$ & $128.0(\mathrm{CH})$ & $4,5,8,10$ \\
\hline 7 & $6.58 \mathrm{dd}(12.1,2.6)$ & $131.3(\mathrm{CH})$ & $5,9,14$ \\
\hline 8 & & $128.4(\mathrm{C})$ & \\
\hline 9 & & $135.2(\mathrm{C})$ & \\
\hline 10 & & $76.4(\mathrm{C})$ & \\
\hline 11 & $6.56 \mathrm{~s}$ & $112.2(\mathrm{CH})$ & $8,12,13,20$ \\
\hline 12 & & $156.9(\mathrm{C})$ & \\
\hline 13 & & $124.4(\mathrm{C})$ & \\
\hline 14 & $6.95 \mathrm{~s}$ & $132.4(\mathrm{CH})$ & $7,9,12$ \\
\hline 15 & $2.17 \mathrm{~s}$ & $15.6\left(\mathrm{CH}_{3}\right)$ & $12,13,14$ \\
\hline 18 & $1.00 \mathrm{~s}$ & $27.2\left(\mathrm{CH}_{3}\right)$ & $3,4,5,19$ \\
\hline 19 & $1.09 \mathrm{~s}$ & $22.4\left(\mathrm{CH}_{3}\right)$ & $3,4,5,18$ \\
\hline 20 & $2.96 \mathrm{~d}(14.2)$ & $51.6\left(\mathrm{CH}_{2}\right)$ & $1,5,8,9,10,11$ \\
\hline & $2.68 \mathrm{~d}(14.2)$ & & \\
\hline 12-OMe & $3.82 \mathrm{~s}$ & $55.3\left(\mathrm{CH}_{3}\right)$ & 12 \\
\hline
\end{tabular}

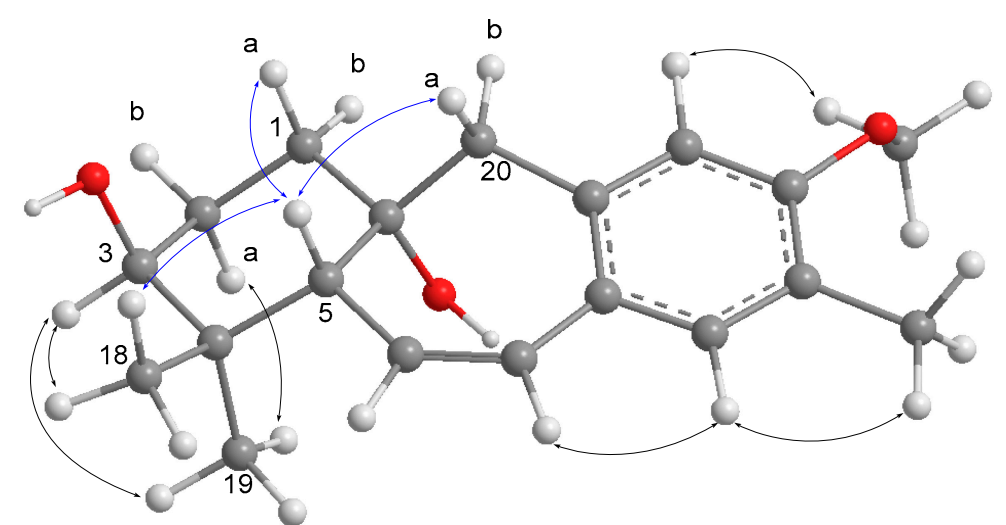

Figure 2. Selected NOE correlations of $\mathbf{1}$.

The structure of dehydrochebulic acid trimethyl ester (original 2, Chart 1) with a cis-methylbutenedioate scaffold was reported from Phyllanthus urinaria by Yao et al. in 1993 [9]. However, the authors proposed the wrong geometry for the methylbutenedioate moiety because of failure to compare the NMR data for this moiety with those reported in the literature. The ${ }^{1} \mathrm{H}$ and ${ }^{13} \mathrm{C}$-NMR data of 2 measured in acetone- $d_{6}$ and pyridine- $d_{6}$ were in good agreement with those reported in the literature [8,9]. In the selective 1D NOESY experiment (Figure 3), irradiation of olefinic H-5 did not show enhancements with other signals, suggesting that the 4,5-double bond in 2 has a trans geometry. A single-crystal X-ray analysis was performed on 2 (Figure 4), which led the absolute configurations to be defined as $2 S, 3 R$ according to the value of Flack parameter 0.09 (14), 
and confirmed the geometry of a $4 E$-double bond. Accordingly, the structure of 2 was revised as $(2 S, 3 R)$-4E-dehydrochebulic acid trimethyl ester (Chart 1, revised 2).



(b)

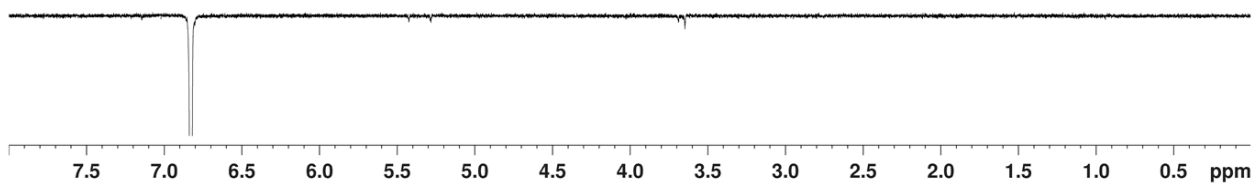

Figure 3. (a) ${ }^{1} \mathrm{H}-\mathrm{NMR}$ spectrum of 2 measured in acetone- $d_{6}$ and (b) selective 1D NOESY spectrum of 2: selective irradiation of $\mathrm{H}-5\left(\delta_{\mathrm{H}}=6.83 \mathrm{ppm}\right)$ using selnogp. 3 Bruker program (parameter set: ns 128 , p12 = $80 \mathrm{~ms}$, and $\mathrm{d} 8=400 \mathrm{~ms})$.

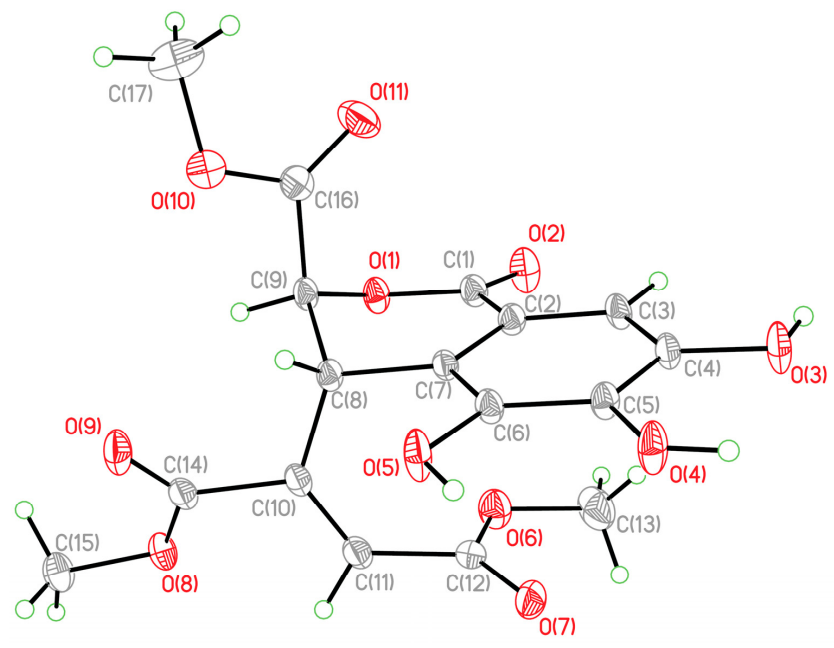

Figure 4. X-ray ORTEP drawing of 2.

In order to continue our exploration for anti-HCV agents from a natural source, the isolated compounds were subjected to anti-HCV and cytotoxic evaluation. As shown in Table 2, the anti-HCV activity of compounds 1-6 was assayed using the cell-based HCV cell culture (HCVcC) infection system, while the toxicity toward human hepatoma Huh7.5 cells was also measured using a 3-(4,5-dimethylthiazol-2-yl)-5-(3-carboxymethoxyphenyl)-2-(4-sulfophenyl)-2H-tetrazolium salt (MTS) assay. In addition, the therapeutic indices $\left(\mathrm{TI}=\mathrm{IC}_{50} / \mathrm{EC}_{50}\right)$ were also calculated to estimate their potency as anti-HCV agents. The result showed that compounds 3-5 possessed better potencies than honokiol (TI = 2.1) [13], a natural anti-HCV agent from Magnolia officinalis [14], with TI values of 6.8, 9.2 , and 2.9 , respectively. 
Table 2. Anti-HCV activities $\left(\mathrm{EC}_{50}\right)$ and cytotoxicity $\left(\mathrm{IC}_{50}\right)$ of 1-6.

\begin{tabular}{|c|c|c|c|}
\hline Compound & $\mathrm{EC}_{50}(\mu \mathrm{M})^{\mathrm{a}}$ & $\mathrm{IC}_{50}(\mu \mathrm{M})^{\mathrm{b}}$ & $(\mathrm{TI})^{\mathrm{c}}$ \\
\hline 1 & $27.4 \pm 1.4$ & $>100$ & $-d$ \\
\hline 2 & $98.4 \pm 2.1$ & $>100$ & $-d$ \\
\hline 3 & $12.8 \pm 3.1$ & $87.1 \pm 5.1$ & 6.8 \\
\hline 4 & $7.7 \pm 2.7$ & $70.5 \pm 4.2$ & 9.2 \\
\hline 5 & $20.8 \pm 2.0$ & $60.7 \pm 2.0$ & 2.9 \\
\hline 6 & $66.7 \pm 1.8$ & $>100$ & $-d$ \\
\hline honokiol & $22.4 \pm 0.5$ & $48.8 \pm 0.8$ & 2.1 \\
\hline
\end{tabular}

\section{Experimental Section}

\subsection{General Experimental Procedures}

Melting point and optical rotation data were recorded on a Yanako MP-500P micro melting point apparatus (Yanaco, Kyoto, Japan) and a JASCO P2000 digital polarimeter (JASCO Corporation, Tokyo, Japan), respectively. IR spectra were recorded as a thin film on a $\mathrm{KBr}$ plate or using a conventional KBr pellet on a Shimadzu IR Prestige21 FT-IR spectrometer (Shimadzu, Milan, Italy). UV data were obtained using a Shimadzu UV-1700 UV/Vis spectrometer (Shimadzu). NMR spectra (400 MHz) were recorded using a Bruker Avance 400 spectrometer equipped with a 5-mm Dual z-gradient probe ${ }^{1} \mathrm{H} /{ }^{13} \mathrm{C}$ (Bruker, Rheinstetten, Germany). HR-APCI-MS and HR-ESI-MS were measured with an LTQ Orbitrap XL mass spectrometer (Thermo Fisher Scientific Corp., Waltham, MA, USA). Column chromatography (CC) was performed on silica gel 60 (230-400 mesh, Merck, Darmstadt, Germany) and RP-18 gel (230-400 mesh, SiliaBond C18, SiliCycle, Quebec City, QC, Canada). Silica gel plates (Kieselgel 60 F254, $0.25 \mathrm{~mm}$, Merck) were used for thin-layer chromatography (TLC) analysis, and spots were visualized by spraying with $10 \% \mathrm{H}_{2} \mathrm{SO}_{4}$ solution followed by heating.

\subsection{Plant Material}

Twigs and leaves of F. virosa were collected in North Pingtung, Taiwan, in August 2013. Botanical identification was performed by Dr. S.-Y. Hwang. A voucher specimen (chao-002) was deposited in the School of Pharmacy, China Medical University.

\subsection{Extraction and Isolation}

The twigs and leaves of $F$. virosa ( $35 \mathrm{~kg}$ ) were crushed and extracted exhaustively with $\mathrm{MeOH}$ $(5 \times 40 \mathrm{~L})$. The organic extract was concentrated to an aqueous suspension and was further partitioned between $\mathrm{CHCl}_{3}$ and $\mathrm{H}_{2} \mathrm{O}$. The $\mathrm{CHCl}_{3}$ extract was washed with $3 \%$ aqueous tartaric acid three times to remove alkaloids. The resulting nonalkaloid extract $(420 \mathrm{~g})$ was fractionated by open column chromatography on silica gel using hexane/EtOAc and EtOAc/MeOH mixtures of increasing polarity to yield 14 fractions. Fraction 9, eluted with EtOAc/MeOH (9:1), was repeatedly separated by RP-18 column chromatography with gradient elution $\left(\mathrm{MeOH} / \mathrm{H}_{2} \mathrm{O}, 5 \%\right.$ to $\left.40 \%\right)$ to yield $2(200.2 \mathrm{mg})$ and 6 $(12.1 \mathrm{mg})$. Fraction 7 was fractionated by silica gel column chromatography using gradient elution (hexane/EtOAc, 100:0 to 53:47) to afford 20 subfractions (7A to 7T). Compounds 1 (100.2 mg), 4 $(266.1 \mathrm{mg}), 3(19.1 \mathrm{mg})$, and $5(80.0 \mathrm{mg})$ were obtained from fraction $7 \mathrm{~L}$ by repeated column chromatography over silica gel with (hexane/EtOAc, 100:0 to 60:40).

$3 \beta, 10 \alpha$-Dihydroxy-12-methoxy-13-methyl-9(10 $\rightarrow 20)$-abeo-ent-podocarpa-6,8,11,13-tetraene (1): pale yellow oil; $[\alpha]_{\mathrm{D}}^{25}+139\left(c 1.65, \mathrm{CHCl}_{3}\right)$; UV (MeOH) $\lambda_{\max }(\log \varepsilon) 214(4.23), 261$ (3.94) nm; IR (neat) $v_{\max }$ 3444, $3003,2953,2931,2870,1610,1568,1504,1446,1435,1384,1336,1315,1257,1217,1114,1097,1045,1020$, 
and $981 \mathrm{~cm}^{-1}$; for ${ }^{1} \mathrm{H}$ - and ${ }^{13} \mathrm{C}-\mathrm{NMR}$ data in $\mathrm{CDCl}_{3}$, see Table 2; (-)-APCI-MS $\mathrm{m} / z 301[\mathrm{M}-\mathrm{H}]^{-}$; (-)-HR-APCI-MS m/z $301.1805[\mathrm{M}-\mathrm{H}]^{-}$(calcd for $\mathrm{C}_{19} \mathrm{H}_{25} \mathrm{O}_{3}, 301.1809$ ).

(2S,3R)-4E-Dehydrochebulic acid trimethyl ester (2): colorless crystal; mp $216-218{ }^{\circ} \mathrm{C}(\mathrm{MeOH}),[\alpha]_{\mathrm{D}}^{25}+15$ (c 28.45, MeOH); UV (MeOH) $\lambda_{\max }(\log \varepsilon) 226$ (4.47), 287 (3.97) nm; IR (KBr) $v_{\max } 3394,3257,1761$, 1752, 1730, 1708, 1649 1622, 1608, 1537, 1494, 1431, 1390, 1369, 1352, 1309, 1278, 1244, 1209, 1180, 1114, 1066, and $1006 \mathrm{~cm}^{-1}$.

\subsection{Crystallographic Data of 2}

A colorless crystal of 2 with sizes of $0.62 \times 0.50 \times 0.47 \mathrm{~mm}^{3}$ was obtained at room temperature by slow evaporation in $\mathrm{MeOH}$ solution. Diffraction intensity data were acquired with a CCD area detector with graphite-monochromated $\mathrm{CuK} \alpha$ radiation $\left(\lambda=1.54178 \AA\right.$ ) . Crystal data for $2: \mathrm{C}_{17} \mathrm{H}_{16} \mathrm{O}_{11}$, $M=396.30$, orthorhombic, $a=7.1567(2) \AA, b=9.7147(3) \AA, c=25.1934(7) \AA, \alpha=90.00^{\circ}, \beta=90.00^{\circ}$, $\gamma=90.00^{\circ}, V=1751.58(9) \AA^{3}, T=150(2) \mathrm{K}$, space group $P 2{ }_{1} 2_{1} 2_{1}, Z=4, \mu(\mathrm{CuK} \alpha)=1.115 \mathrm{~mm}^{-1}$, 6642 reflections collected, 3372 independent reflections $\left(R_{\text {int }}=0.0199\right)$. The final $R_{1}$ values were $0.0298(I>2 \sigma(I))$. The final $w R\left(F^{2}\right)$ values were $0.0787(I>2 \sigma(I))$. The final $R_{1}$ values were 0.0315 (all data). The final $w R\left(F^{2}\right)$ values were 0.0800 (all data). The goodness of fit on $F^{2}$ was 1.028 . Flack parameter $=0.09(14)$. Crystallographic data for this compound have been deposited with the Cambridge Crystallographic Data Centre (deposition number CCDC 1484756) (Supplementary Materials). Copies of the data can be obtained, free of charge, on application to the Director, CCDC, 12 Union Road, Cambridge CB21EZ, UK [fax: +44(0)-1223-336033 or e-mail: deposit@ccdc.cam.ac.uk].

\subsection{Infection Inhibition Assay}

The JC1-Luc2A HCV reporter viral particles were prepared as described previously $[15,16]$. In brief, in vitro-transcribed genomic JC1-Luc2A RNA was delivered into Huh7.5.1 cells by electroporation. The virus-containing supernatant was collected for 4 days, clarified by low-speed centrifugation, passed through a filter with a pore size of $0.45 \mu \mathrm{m}$, and quantitated by fluorescent focus assay. The MTS assay was used to determine the cell viability, while HCV infection inhibition assay was performed according to the published protocol in $[6,15]$. Huh7.5.1 cells were seeded into the 96-well culture plates at a cell density of $1 \times 10^{4}$ cells/well for $24 \mathrm{~h}$ followed by incubation with HCV reporter virus (with $0.1 \mathrm{MOI}$ ) for an additional $4 \mathrm{~h}$. After removing the virus containing supernatant, the cells were washed 3 times with PBS and then replaced with medium containing indicated compound for $72 \mathrm{~h}$. The luciferase activity assay was performed by the collected cell lysates. Honokiol, a known natural product with anti-HCV activity, was used as an inhibition positive control.

\section{Conclusions}

A new $9(10 \rightarrow 20)$-abeo-ent-podocarpane (1) and five known compounds were isolated from the twigs and leaves of F. virosa. The structures of the isolates were identified on the basis of NMR, MS, and IR spectroscopic data. The structure $4 E$-dehydrochebulic acid trimethyl ester was revised and its absolute configuration was determined for the first time. Comparing the present study with our prior investigation [4-7], it was found that the diversity in chemical constitutions of the roots were quite different from those of the twigs and leaves of $F$. virosa. Furthermore, $3 \beta, 12$-dihydroxy-13-methylpodocarpa-6,8,11,13-tetraene (4) was found to be abundant in the twigs and leaves; however, the 12-O-methyl analogue of 4 was isolated as the main constituent in the roots [4]. Although the $9(10 \rightarrow 20)$-abeo-ent-podocarpane skeleton had been reported from the roots of this plant [6], it was still rare in a natural source. The present anti-HCV evaluation suggested that the ent-podocarpane derivatives might be the active ingredients in this plant.

Supplementary Materials: Supplementary materials can be accessed at: http:/ /www.mdpi.com/1420-3049/21/ 9/1239/s1. 
Acknowledgments: The authors are grateful for financial support from the Ministry of Science and Technology (MOST102-2113-M-039-001, MOST103-2320-B-039-004-MY3, and MOST104-2911-I-002-302). This study was also supported in part from the grant of Chinese Medicine Research Center, China Medical University (the Ministry of Education, the Aim for the Top University Plan).

Author Contributions: Chih-Hua Chao and Yang-Chang $\mathrm{Wu}$ conceived and designed the experiments; Ying-Ju Lin, Yung-Ju Yeh, and Ju-Chien Cheng performed the biological assay; Hui-Chi Huang and Tian-Shung Wu analyzed the data; Syh-Yuan Hwang contributed to the collection and species identification.

Conflicts of Interest: The authors declare no conflict of interest.

\section{References}

1. Kamatenesi-Mugisha, M.; Oryem-Origa, H. Traditional herbal remedies used in the management of sexual impotence and erectile dysfunction in western Uganda. Afr. Health Sci. 2005, 5, 40-49. [PubMed]

2. Chen, S.-K.; Chen, B.-Y.; Li, H. Flora of China; Science Press: Beijing, China, 1997; Volume 44, pp. 68-71.

3. Wu, Z.-L.; Zhao, B.-X.; Huang, X.-J.; Tang, G.-Y.; Shi, L.; Jiang, R.-W.; Liu, X.; Wang, Y.; Ye, W.-C. Suffrutines $A$ and $B$ : a pair of $Z / E$ isomeric indolizidine alkaloids from the roots of Flueggea suffruticosa. Angew. Chem. Int. Ed. 2014, 53, 5796-5799. [CrossRef] [PubMed]

4. Chao, C.-H.; Cheng, J.-C.; Shen, D.-Y.; Wu, T.-S. Anti-hepatitis C virus dinorditerpenes from the roots of Flueggea virosa. J. Nat. Prod. 2014, 77, 22-28. [CrossRef] [PubMed]

5. Chao, C.-H.; Cheng, J.-C.; Hwang, T.-L.; Shen, D.-Y.; Wu, T.-S. Trinorditerpenes from the roots of Flueggea virosa. Bioorg. Med. Chem. Lett. 2014, 24, 447-449. [CrossRef] [PubMed]

6. Chao, C.-H.; Cheng, J.-C.; Shen, D.-Y.; Huang, H.-C.; Wu, Y.-C.; Wu, T.-S. Terpenoids from Flueggea virosa and their anti-hepatitis $C$ virus activity. Phytochemistry 2016, 128, 60-70. [CrossRef] [PubMed]

7. Chao, C.-H.; Cheng, J.-C.; Shen, D.-Y.; Huang, H.-C.; Wu, Y.-C.; Wu, T.-S. 13-Methyl-3,4-seco-entpodocarpanes, rare C18-diterpenoids from the roots of Flueggea virosa. RSC Adv. 2016, 6, 34708-34714. [CrossRef]

8. Camacho-Luis, A.; Gayosso-De-Lucio, J.A.; Torres-Valencia, J.M.; Munoz-Sanchez, J.L.; Alarcon-Hernandez, E.; Lopez, R.; Barron, B.L. Antioxidant Constituents of Geranium bellum Rose. J. Mex. Chem. Soc. 2008, 52, 103-107.

9. Yao, Q.-Q.; Zuo, C.-X. Chemical studied on the constituents of Phyllanthus urinaria L. Acta Pharm. Sin. 1993, 28, 829-835. [CrossRef] [PubMed]

10. Yuan, W.; Lu, Z.; Liu, Y.; Meng, C.; Cheng, K.-D.; Zhu, P. Three new podocarpane-type diterpenoids from callus of Securinega suffruticosa. Chem. Pharm. Bull. 2005, 53, 1610-1612. [CrossRef] [PubMed]

11. Pan, H.; Lundgren, L.N.; Andersson, R. Triterpene caffeates from bark of Betula pubescens. Phytochemsitry 1994, 37, 795-799. [CrossRef]

12. Yang, J.-H.; Lu, H.; Huang, R.; Wang, Y.S. Flavonoids from leaves and twigs of Stachyurus himalaicus var. himalaicus. Chem. Nat. Compd. 2011, 47, 112-113. [CrossRef]

13. Lan, K.-H.; Wang, Y.-W.; Lee, W.-P.; Lan, K.-L.; Tseng, S.-H.; Hung, L.-R.; Yen, S.-H.; Lin, H.-C.; Lee, S.-D. Multiple effects of Honokiol on the life cycle of hepatitis C virus. Liver Int. 2012, 32, 989-997. [CrossRef] [PubMed]

14. Shih, H.-C.; Hwang, T.-L.; Chen, H.-C.; Kuo, P.-C.; Lee, E.-J.; Lee, K.-H.; Wu, T.-S. Honokiol dimers and magnolol derivatives with new carbon skeletons from the roots of Magnolia officinalis and their inhibitory effects on superoxide anion generation and elastase release. PLoS ONE 2013, 8, e59502. [CrossRef] [PubMed]

15. Huang, J.-T.; Tseng, C.-P.; Liao, M.-H.; Lu, S.-C.; Yeh, W.-Z.; Sakamoto, N.; Chen, C.-M.; Cheng, J.-C. Hepatitis $\mathrm{C}$ virus replication is modulated by the interaction of nonstructural protein NS5B and fatty acid synthase. J. Virol. 2013, 87, 4994-5004. [CrossRef] [PubMed]

16. Blight, K.J.; McKeating, J.A.; Rice, C.M. Highly permissive cell lines for subgenomic and genomic hepatitis C virus RNA replication. J. Virol. 2002, 76, 13001-13014. [CrossRef] [PubMed]

Sample Availability: Samples of the compounds $\mathbf{1}$ and $\mathbf{2}$ are available from the authors.

(C) 2016 by the authors; licensee MDPI, Basel, Switzerland. This article is an open access article distributed under the terms and conditions of the Creative Commons Attribution (CC-BY) license (http://creativecommons.org/licenses/by/4.0/). 